\title{
Fulvestrant Does Not Have Antagonistic Effect on 17ß-estradiol's Anti-proliferative Action in Cultured Chinese Hamster Ovarian Cell Line
}

\author{
Hyun Hee Kim ${ }^{1}$, Hyeong Cheol Park ${ }^{2}$ and Gyesik Min ${ }^{3 *}$ \\ ${ }^{1}$ Department of Pharmaceutical Engineering, College of Bioscience, Gyeongnam National University of Science \& Technology, Jinju 660-758, Korea \\ ${ }^{2}$ Division of Applied Life Science (Brain Korea 21 Program) and Plant Molecular Biology and Biotechnology Research Center, Gyeangsang \\ National University, Jinju 660-701, Korea \\ ${ }^{3}$ Department of Nursing, College of Bioscience, Gyeongnam National University of Science \& Technology, Jinju 660-758, Korea
}

Received November 7, 2013 /Revised January 5, 2014 / Accepted January 8, 2014

\begin{abstract}
Estrogen can promote or inhibit cellular proliferation depending on tissue cell types and physiological condition and acts through the signal transduction pathways mediated primarily by estrogen receptors. This study examined the effects of fulvestrant (Ful), a well-known antagonist for the estrogen receptor, on the action of $17 \beta$-estradiol (E2) with respect to the proliferation and apoptosis of Chinese hamster ovarian ( $\mathrm{CHO}$ ) cells. We used different concentrations of E2, Ful, and E2 plus Ful during different treatment durations. Treatment with 15-40 $\mu \mathrm{M}$ E2 significantly inhibited proliferation in a time-dependent manner, although it had no influence in concentrations up to $1 \mu \mathrm{M}$. Interestingly, Ful at 10-40 $\mu \mathrm{M}$ also inhibited cellular proliferation in both a concentration- and time-dependent manner. In addition, Ful enhanced rather than decreased the inhibitory effect on cellular proliferation by E2 in combined treatment for 10 days. Thus, Ful does not appear to have an antagonistic effect on estrogen's anti-proliferative action in CHO cells. In TUNEL assays to confirm DNA fragmentation by E2 and/or Ful, CHO cells treated with $20 \mu \mathrm{M}$ E2 showed a TUNEL-positive reaction in most DAPI-stained nuclei, and cells treated with either $40 \mu \mathrm{M}$ Ful or $40 \mu \mathrm{M}$ Ful plus $20 \mu \mathrm{M}$ E2 also exhibited a TUNEL-positive reaction but at a lower rate compared to the E2-treated cells. These results indicate that Ful does not have an antagonistic effect on estrogen's anti-proliferative action in $\mathrm{CHO}$ cells, suggesting that the anti-proliferative and apoptosis-related mechanism(s) through DNA fragmentation by E2 and Ful may be mediated by different signal transduction pathways.
\end{abstract}

Key words : 17ß-estradiol (E2), Chinese hamster ovarian (CHO), DNA fragmentation, fulvestrant, proliferation

\section{서 론}

에스트로겐은 주로 성장중인 난포 및 태반에서 콜레스테롤 로부터 합성되지만 간, 심장, 피부, 및 뇌와 같은 비성선 기관 에서도 합성될 수 있다[6]. 에스트로겐은 난소 내 난포의 성장 과 발달, 여성의 제2차 성징 발현, 배란을 위한 성선자극호르 몬 분비의 조절, 프로게스테론 반응을 위한 조직준비, 및 뼈의 유지 등 다양한 생리적 기능을 수행한다 $[15,29]$. 특히 $17 \beta$ -estradiol (E2)은 estrone 또는 estriol에 비하여 에스트로겐 수 용체(ER)에 대한 강한 친화력을 가지고 있으며, 생리적으로 주요한 활성을 갖는 내인성 호르몬이다[4].

\footnotetext{
*Corresponding author

Tel : +82-55-751-3651, Fax : +82-55-751-3659

E-mail : g-min@gntech.ac.kr

This is an Open-Access article distributed under the terms of the Creative Commons Attribution Non-Commercial License (http://creativecommons.org/licenses/by-nc/3.0) which permits unrestricted non-commercial use, distribution, and reproduction in any medium, provided the original work is properly cited
}

E2의 생물학적 효과는 다양한 ER 신호전달경로를 통하여 매개된다. 전형적인 리간드-의존성 경로에서, E2는 원형질 막 또는 세포질 내에 존재하는 $\mathrm{ER}$ 과 결합한 다음 각기 고유한 신호전달경로 또는 핵 이동 후 유도하는 estrogen-responsive genes의 발현조절을 통해 표적세포 내 반응을 일으킨다. 또한 리간드의 존재 여부와 상관 없이 ER은 성장인자 또는 $\mathrm{CAMP}$ 에 의해 유도되는 세포 내 인산화효소 경로의 활성화에 의한 인산화를 통하여 세포의 다양한 반응을 조절한다. 뿐만 아니 라 E2-ER 복합체는 표적유전자의 estrogen response elements (EREs) 존재 여부와 상관없이 Fos 또는 Jun과 같은 다른 전사 조절인자들과 결합하여 AP-1과 같은 alternative response elements를 포함하는 유전자들의 전사를 조절한다. 특히 원형질 막에 위치한 ER과 결합한 에스트로겐은 세포 내 효소들의 연 속적 활성화 반응을 유도하는 빠른 신호전달경로를 통하여 생리적 반응을 유도한다[13, 25].

폐경 이전 여성의 난소는 내인성 에스트로겐의 주된 공급원 일 뿐만 아니라 에스트로겐의 중요한 표적조직들 중의 하나이 다. $\mathrm{ERa}$ 와 $\mathrm{ER} \beta$ 는 정상적인 난소의 표면상피세포뿐만 아니라 난소암세포에서도 발현되는데, 특히 난소세포에 대한 에스트 
로겐의 생물학적 효과는 $\mathrm{ER}$ 을 발현하는 다양한 종류의 난소암 세포들에서 증식을 촉진하는 것으로 보고되었다 $[1,3,7,9,17$, 18, 27]. 특히 암화된 불멸난소 상피세포(IOSE-29EC)의 배양에 서 $10^{-8}-10^{-6} \mathrm{M}$ 의 E2 처리는 DNA 내 thymidine의 병합과 DNA 의 함량을 증가시킴으로써 세포증식을 초래할 뿐만 아니라 antiapoptotic factors 중의 하나에 해당하는 Bcl-2의 발현을 촉진 시켜 tamoxifen에 의해 유도된 세포사멸을 감소시켰다[5]. 또한 에스트로겐은 유방암 발생의 주요 원인 호르몬으로 알려져 있 으며 유선 상피세포의 증식을 유도하여 암의 진행에 주요한 역할을 하는 것으로 보고되어 왔다[4]. 이러한 에스트로겐의 암 화 유도는 세포 증식의 촉진뿐만 아니라 세포침윤을 통한 전이 를 일으켜 암의 진행에 영향을 미치는 것으로 여겨진다[7].

한편, 이러한 에스트로겐의 세포증식 효과와는 달리 다양한 정상 조직세포 및 다른 유형의 암세포들에서 세포증식 억제효 과도 나타내는 것으로 보고되어 있다. 최근의 연구에서, 에스 트로겐은 신경유래 세포, 파골세포 및 흥선세포 등과 같은 비 생식 조직세포뿐만 아니라 유방암세포와 전립선암세포 등과 같은 생식관련 조직유래 암세포에서 세포사멸을 촉진시켰을 뿐만 아니라 증식을 억제하는 것으로 보고되었다[7, 28]. 유방 암 세포주인 MCF-7으로부터 장기간 에스트로겐 결핍에 의해 유래된 LTED (long-term estrogen deprivation) 세포는 0.1-10 $\mathrm{nM}$ 의 E2 처리시 대조군에 비하여 약 $60 \%$ 의 세포성장을 억제 시켰으며, DNA 분절 유도 및 death receptor protein Fas와 이의 리간드 FasL의 발현을 증가시켰다. 이러한 결과는 에스 트로겐이 폐경 후의 호르몬 의존성 유방암 환자에서 Fas에 의해 매개된 세포사멸을 일으켜 종양의 퇴행을 촉진시킬 수 있음을 보고하였다[24]. 파골세포형성 유도물질인 receptor activator of nuclear factor kappa-B ligand (RANK-L)를 처리 한 쥐의 파골세포주에서 $10^{8} \mathrm{M}$ 의 $\mathrm{E} 2$ 처리는 파골세포의 분화 와 $\beta 3$-integrin의 발현을 감소시켜 세포부착을 억제하였으며, 핵의 응축 및 $\mathrm{Bax} / \mathrm{Bcl}-2$ 의 비율을 증가시켜 세포사멸을 유도 하는 것으로 보고되었다[22]. ER DNA 도입에 의해 영구적으 로 형질전환된 생쥐 섬유아세포주에서 $\mathrm{E} 2$ 는 세포성장을 억제 시켰을 뿐만 아니라 핵의 응집 및 세포사멸을 유도하였으나 $\mathrm{ER}$ 이 발현되지 않은 생쥐 섬유아세포주에서는 $\mathrm{E} 2$ 에 의한 세 포성장 억제효과가 나타나지 않음으로써, 이러한 E2에 의한 세포증식 억제효과가 ER를 통해 매개됨이 보고된 바 있다[10]. 또한 인간 관상동맥 내피세포에서 E2 처리는 시간-의존적인 세포성장의 억제와 DNA 가닥 절단 및 핵의 분절화를 유도하 였을 뿐만 아니라, FasL mRNA 발현과 단백질의 분비를 증가 시켜 Fas/FasL 신호전달경로를 활성화함으로써 E2에 의한 세 포사멸 효과를 매개하는 것으로 보고되었다[23]. 그러나 난소 세포주에서 에스트로겐에 의한 세포증식 억제효과는 아직까 지 보고된 바 없다.

Fulvestrant (Ful)는 E2의 7a-alkylsulphinyl 유사물질로서, 대표적인 antiestrogen 및 선택적인 ER down-regulators 중의
하나이다. Ful은 ER에 대한 agonist 작용을 갖지 않는 순수한 antagonist로써, 여성의 진행성 유방암 치료에 사용되어왔다. 4-hydroxytamoxifen과 같은 selective estrogen receptor modulators (SERMs)는 ERa에 대한 antagonist 또는 부분적 agonist로써 작용하는데 비하여[30], Ful은 ER에 대한 E2의 결합 을 경쟁적으로 억제하며 $\mathrm{ER}$ 의 이량체화 및 에너지-의존성 핵 위치이동을 차단한다. 핵으로 진입하는 일부 Ful - ER 복합체 또한 ER의 $\mathrm{AF}$ (activation function)-1과 AF-2의 기능 모두를 상실하였기 때문에 전사적으로 불활성 된 상태로 남아있다. 뿐만 아니라 E2와 결합된 ER과는 달리, Ful- ER 복합체는 불 안정하여[16], proteosome에 의한 ERa 단백질의 분해를 촉진 시켜 에스트로겐의 신호전달을 차단함으로써 에스트로겐-의 존성 유방암세포의 증식을 억제하고 세포사멸을 유도하는 것 으로 보고되었다[30]. 이러한 결과와 일치하게, 다수의 연구에 서 Ful이 ERa를 발현하는 세포들(인간 유선상피세포, 유방암 세포 및 비소형세포 폐암)의 증식을 억제하고 세포사멸을 유 도하는 것으로 보고되었다[21, 26, 31].

따라서, 에스트로겐과 Ful의 다양하고 때로는 상반적인 생 리적 작용을 규명하기 위해서는 유래된 표적 조직세포의 유형 과 세포의 특이적인 생리적 상태에 따라 독립적으로 연구되어 야 할 필요가 있다. 본 연구에서는 특히 유방암세포에서 $\mathrm{ER}$ 에 대한 길항제로 잘 알려진 $\mathrm{Ful}$ 이 $\mathrm{CHO}$ 세포주의 증식 및 세포 사멸에 미치는 영향과 $\mathrm{E} 2$ 에 의한 $\mathrm{CHO}$ 세포증식과 사멸에 미 치는 효과를 조사하고자 하였다.

\section{재료 및 방법}

\section{Cell-line}

$\mathrm{CHO}$ 세포주는 american type culture collection (ATCC)으 로부터 구입되었으며, 30-40회 계대배양을 통하여 실험에 사 용되었다. 배양을 위한 Dulbecco's modified Eagle's medium (DMEM) 및 태아송아지 혈청은 Gibco Invitrogen (Grand Island, NY, USA), 세포배양 플레이트는 Nunc a/s (Roskilde, Denmark), 그리고 E2와 Ful은 Sigma (St. Louis, MO, USA)로 부터 각각 구입되었다.

\section{Cell culture}

$\mathrm{CHO}$ 세포는 $5 \%$ 태아송아지 혈청, $100 \mathrm{unit} / \mathrm{ml}$ 의 penicillin 및 $100 \mu \mathrm{g} / \mathrm{ml}$ 의 streptomycin이 첨가된 DMEM에서 배 양을 유지하였다. 배양된 세포는 phosphate buffered saline (PBS)에 용해된 $0.05 \%$ trypsin 및 $2 \mathrm{mM} \mathrm{EDTA}$ 로 $37^{\circ} \mathrm{C}$ 에서 5 분간 처리하여 $10 \mathrm{~cm}$ 플레이트로부터 분리하고, trypan blue 염색을 통한 hemocytometer로 세포를 계수한 다음, 96-well 또는 48-well 플레이트에 균등히 분주하여 E2 또는 Ful 처리 전 $5 \% \mathrm{CO}_{2}, 37^{\circ} \mathrm{C}$ 에서 12 시간 동안 배양하였다. 


\section{Cell proliferation assay}

다양한 농도의 E2 $(0,0.01,0.1,1,10,15,20,40 \mu \mathrm{M}$ in EtOH) 및 Ful $(0.01,0.1,1,10,20,40 \mu \mathrm{M}$ in DMSO)을 96-well 또는 48-well 플레이트에 균등히 분주된 $\mathrm{CHO}$ 배양세포 3,000 cells/well for 96-well 플레이트, 4,000 cells/well for 48-well 플레이트)에 첨가한 다음, 각각 6 일, 8 일 그리고 10 일 동안 배 양하였다. 처리된 각 well 내의 배양세포는 48 시간 마다 동일 한 농도의 E2 또는 Ful을 포함하는 신선한 배지로 교체하여 배양하였다. 호르몬 처리에 따른 $\mathrm{CHO}$ 세포의 증식에 미치는 효과는 시약공급자의 protocol에 따라 CellTiter-Glo® luminescent cell viability assay (Promega, Madison, WI, U.S.A.) 에 의해 분석되었다. 간단히 말하면, 세포를 함유하는 플레이 트의 배양액을 제거한 후, $100 \mu \mathrm{l}$ 의 새로운 배양액과 동일한 양의 CellTiter-Glo® reagent를 혼합하여 각 well에 $200 \mu 1$ 의 반응혼합액을 첨가한 다음 orbital shaker에서 2분간, 이후 정 지 상태에서 8 분간 반응시킨 후 luminometer를 이용하여 발 광양(luminescence)을 측정하였다. 이러한 실험은 각각 3회 반 복하였으며, 측정값은 luminescence/well로 표시하였다.

\section{TUNEL assay}

$20 \mu \mathrm{M} \mathrm{E2}, 40 \mu \mathrm{M}$ Ful 또는 $20 \mu \mathrm{M}$ E2 plus $40 \mu \mathrm{M}$ Ful 혼합물 을 8-chamber slide에 균등히 분주된 $\left(5 \times 10^{4}\right.$ cells) $\mathrm{CHO}$ 세포주 에 첨가한 다음 2 일 동안 배양하였다. 각 처리 별 세포사멸은 시약공급자의 protocol에 따라 Click-iT® TUNEL assay (Invitrogen)에 의해 분석되었다. 간단히 말하면, 세포를 함유 하는 chamber의 배양액을 제거하고 PBS로 2회 수세한 다음 4\% paraformaldehyde로 실온에서 15분간 세포를 고정하였 다. 고정액을 제거한 후 순차적으로 permeabilization reagent $(0.25 \%$ Triton® X-100 in PBS)와 TdT (terminal deoxynucleotidyl transferase) 반응용액을 실온에서 각각 20분 및 10 분간 처리하여 분절된 DNA의 $3^{\prime}$ 말단에 표지 뉴클레오티드 를 병합하였다. 그리고 TUNEL assay에 대한 양성 대조군은 permeabilization reagent로 반응시킨 다음 DNase I을 처리하 여 DNA의 인위적인 분절을 유도하였으며, 음성 대조군은 $\mathrm{TdT}$ 를 제외한 $\mathrm{TdT}$ 반응용액을 사용하였다. 표지 뉴클레오티 드가 병합된 각 처리군의 $\mathrm{CHO}$ 세포에 대하여 Click-iT® reaction cocktail을 첨가한 다음, 실온에서 30분간 배양함으로써 병합된 새로운 뉴클레오티드에 대한 형광반응을 유도하였다. 형광반응에 대한 background 염색은 3\% BSA (in PBS)에서 2분간 2회 처리하여 최소화시켰으며, DAPI로 DNA를 대조 염색한 다음 형광현미경을 이용하여 DNA의 분절을 확인하였다.

\section{Statistical analysis}

실험결과는 평균 $\pm \mathrm{SE}$ 로 표시되었으며, 처리군 사이의 통계 적 유의성은 Student's $t$-test에 의해 결정되었다. $p \times 0.05$ 의 값 은 통계적으로 유의성이 있음을 의미한다.

\section{결 과}

\section{농도 및 처리기간에 따른 $\mathrm{E} 2$ 의 $\mathrm{CHO}$ 세포증식 억제효과}

배양된 $\mathrm{CHO}$ 세포를 다양한 농도의 $\mathrm{E} 2$ 로 각각 6, 8 및 10 일 간 처리하였을 경우, 0.01-1 $\mu \mathrm{M}$ 의 농도에서는 모든 처리기간 에서 대조군(ethanol)과 비교하여 세포증식에 차이를 보이지 않았으나 $10 \mu \mathrm{M}$ 의 E2는 6일 및 8 일 처리기간을 제외한 10 일 동안의 처리에서 평균 약 $50 \%$ 의 세포증식 감소효과를 보였다 (Fig. 1C).

한편, 15-40 $\mu \mathrm{M}$ 의 E2는 모든 처리기간에서 현저한 세포증 식 억제효과를 나타내었다. 즉, 6일 동안의 처리에서 $15 \mu \mathrm{M}$, $20 \mu \mathrm{M}$ 및 $40 \mu \mathrm{M}$ 의 E2는 각각 평균 $43 \%, 64 \%$ 및 $73 \%$ 의 증식 감소효과를 나타내었으며, 8 일의 경우 각각 평균 $48 \%, 78 \%$ 및 $87 \%$ 의 보다 큰 증식 감소효과를 나타내었다(Fig. 1A-1B). 흥미롭게도, 10 일 동안의 E2 처리는 동일한 각 농도에 대하여 평균 $83 \%, 95 \%$ 및 $97 \%$ 의 현저한 세포증식 감소효과를 보였다 (Fig. 1C).

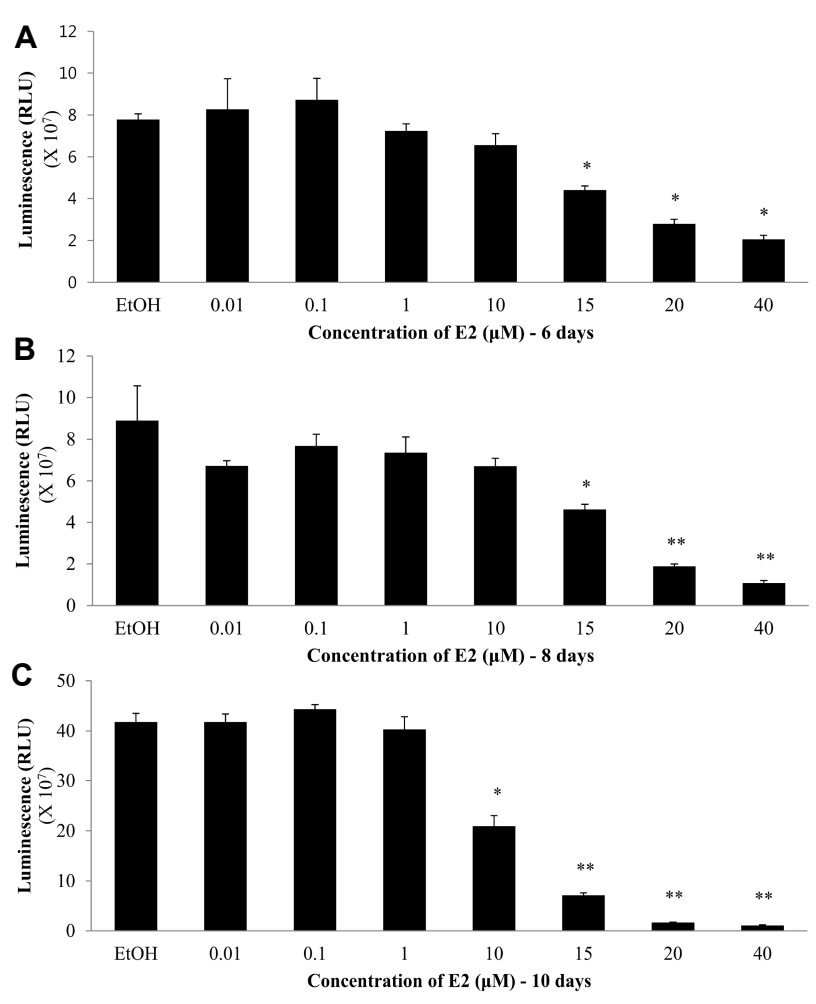

Fig. 1. Inhibitory effects of $17 \beta$-estradiol on cellular proliferation of $\mathrm{CHO}$ as measured by cell proliferation assay. $\mathrm{CHO}$ cells were incubated for 6 days (A), 8 days (B) or 10 days $(\mathrm{C})$ with either $0.2 \%$ ethanol $(\mathrm{EtOH}$; control) or different concentrations of 17ß-estradiol (E2) as indicated. Values are expressed as means \pm SE from three independent experiments. * indicates $p<0.05$ and ** indicates $p<0.01$ as compared to ethanol treatment. 


\section{농도 및 처리기간에 따른 $\mathrm{Ful}$ 의 $\mathrm{CHO}$ 세포증식 억제효과}

배양된 $\mathrm{CHO}$ 세포에 다양한 농도의 Ful로 각각 6,8 및 10일 동안 처리하였을 경우, 0.01-1 $\mu \mathrm{M}$ 의 농도에서는 대조군 (DMSO)과 비교하여 세포증식에 차이를 보이지 않았지만, 20 $\mu \mathrm{M}$ 이상의 농도 $(20,40 \mu \mathrm{M})$ 에서는 모든 처리기간에서 세포증 식 억제효과를 나타내었다. 즉, 6 일 동안의 Ful처리는 $20 \mu \mathrm{M}$ 및 $40 \mu \mathrm{M}$ 의 농도에서 각각 평균 $23 \%$ 및 $28 \%$ 의 증식 억제효과 를 나타내었으며(Fig. 2A), 8일 동안의 처리에서는 각각 평균 $18 \%$ 및 $27 \%$ 의 증식 억제효과를 나타내었다(Fig. 2B). 이와 마 찬가지로, 10 일 동안의 처리에서도 Ful의 동일한 농도에 대하 여 각각 평균 $22 \%$, 및 $35 \%$ 의 농도-의존적인 세포증식 억제효 과를 나타내었다(Fig. 2B).

\section{농도 및 처리기간에 따른 E2 plus Ful의 $\mathrm{CHO}$ 세포증식 억제효과}

배양된 $\mathrm{CHO}$ 세포에서 동일한 농도의 E2 $(20 \mu \mathrm{M})$ 를 처리할 경우, 다양한 농도의 Ful에 의한 세포증식 억제효과를 조사하 였다. 6일 동안의 처리에서는 사용된 Ful의 모든 농도가 E2에
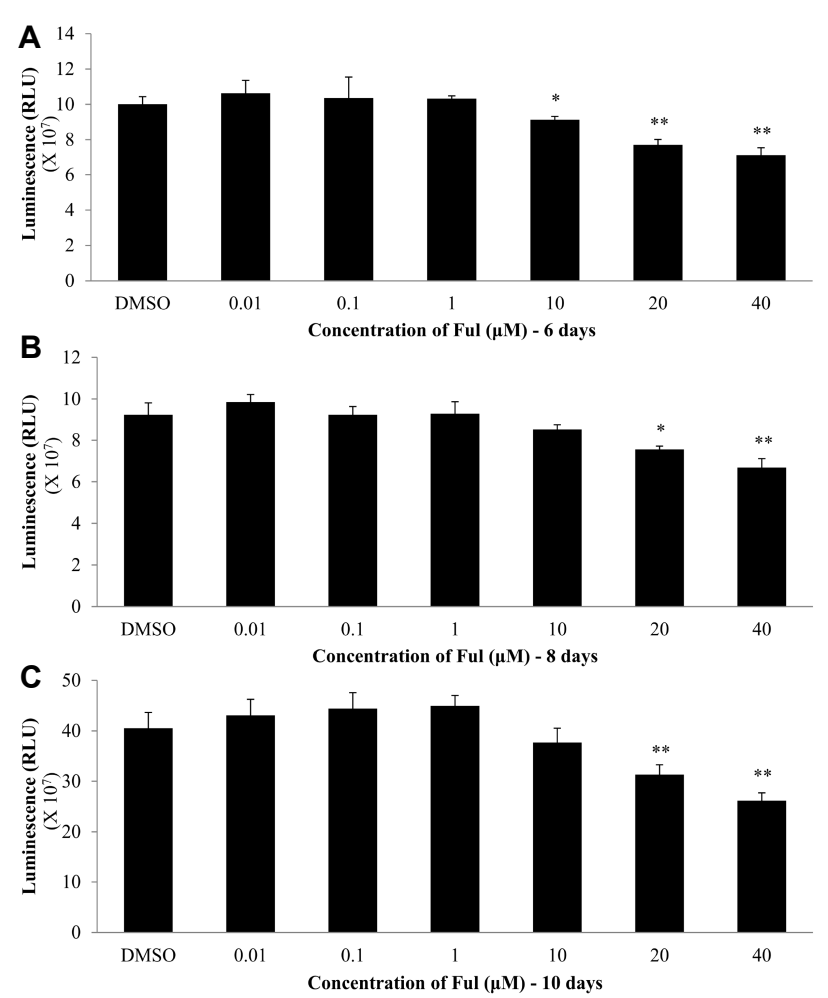

Fig. 2. Inhibitory effects of fulvestrant on cellular proliferation of $\mathrm{CHO}$ as measured by cell proliferation assay. $\mathrm{CHO}$ cells were incubated for 6 days (A), 8 days (B) or 10 days $(\mathrm{C})$ with either $0.4 \%$ DMSO (control) or different concentrations of fulvestrant (Ful) as indicated. Values are expressed as means $\pm \mathrm{SE}$ from three independent experiments. * indicates $p<0.05$ and ** indicates $p<0.01$ as compared to DMSO treatment.
의한 세포증식 억제효과에 통계적으로 유의성 있는 영향을 미치지 않았으나, 특히 $20 \mu \mathrm{M}$ 및 $40 \mu \mathrm{M}$ 의 Ful은 E2에 의한 세포증식 억제효과를 각각 평균 $12 \%$ 및 $18 \%$ 증가시켰다(Fig. 3A). 8 일 동안의 처리에서는 $1 \mu \mathrm{M}$ 및 $40 \mu \mathrm{M}$ 의 Ful이 E2에 의한 세포증식 억제효과를 각각 평균 $21 \%$ 및 $23 \%$ 의 유의성 있는 증가를 보였다(Fig. $3 \mathrm{~B})$. 한편, 10 일 동안의 처리에서는 $0.1 \mu \mathrm{M}$ 을 제외한 모든 농도의 $\mathrm{Ful}$ 이 E2에 의한 세포증식 억제 효과를 촉진시키는 것으로 나타났다. 즉, $0.01 \mu \mathrm{M}, 1 \mu \mathrm{M}, 10$ $\mu \mathrm{M}, 20 \mu \mathrm{M}$ 및 $40 \mu \mathrm{M}$ 의 Ful은 $\mathrm{E} 2$ 에 의한 세포증식 억제효과를 각각 평균 $6 \%, 21 \%, 16 \%, 19 \%$ 및 $23 \%$ 증가시켰다(Fig. 3C).

\section{$\mathrm{E} 2, \mathrm{Ful}$ 및 E2 plus Ful에 의한 DNA 분절 효과}

$\mathrm{E} 2$ 와 $\mathrm{Ful}$ 의 혼합용매 $(0.1 \% \mathrm{EtOH}+0.4 \% \mathrm{DMSO}), 20 \mu \mathrm{M}$ 의 $\mathrm{E} 2,40 \mu \mathrm{M}$ 의 Ful 또는 이들의 혼합물(20 $\mu \mathrm{M}$ E2 plus $40 \mu \mathrm{M}$ $\mathrm{Ful}$ 로 각각 처리된 $\mathrm{CHO}$ 세포에 대하여 $\mathrm{DNA}$ 분절효과를
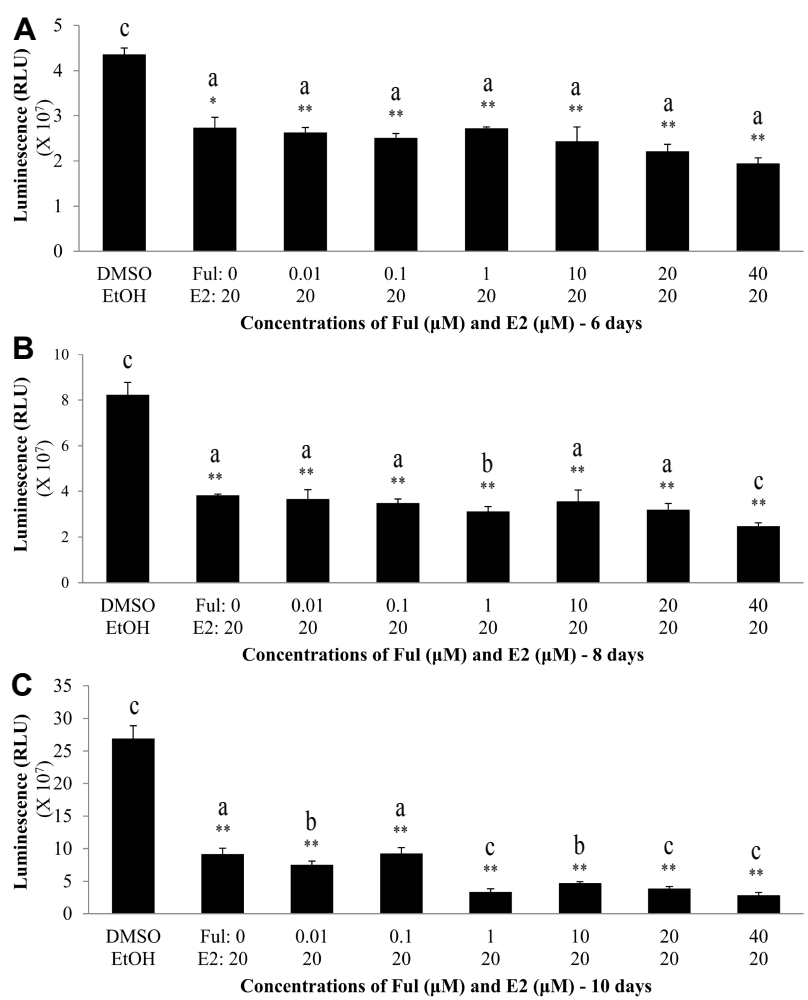

Fig. 3. Inhibitory effects of $17 \beta$-estradiol plus fulvestrant on cellular proliferation of $\mathrm{CHO}$ as measured by cell proliferation assay. $\mathrm{CHO}$ cells were incubated for 6 days (A), 8 days (B) or 10 days (C) with either $0.1 \%$ ethanol plus $0.4 \%$ DMSO (control) or different concentrations of fulvestrant (Ful) in the presence of $20 \mu \mathrm{M}$ 17ß-estradiol (E2) as indicated. Values are expressed as means $\pm \mathrm{SE}$ from three independent experiments. * indicates $p<0.05$ and ** indicates $p<0.01$ as compared to control. Different alphabet letters indicate statistically significant difference between $20 \mu \mathrm{M}$ E2 and each treatment (b indicates $p<0.05$ and $c$ indicates $p<0.01$ ). 
A

(a) $\mathrm{PO}$
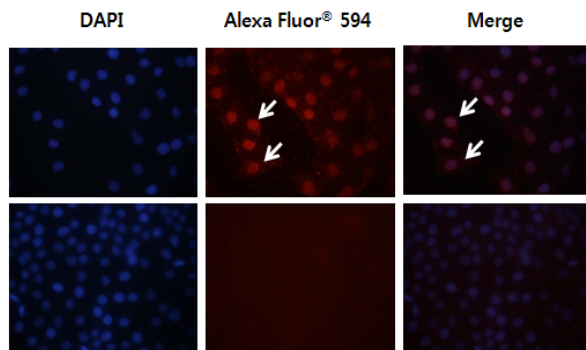

(c) EtOH $(0.1 \%)+$ DMSO $(0.4 \%)$

(d)
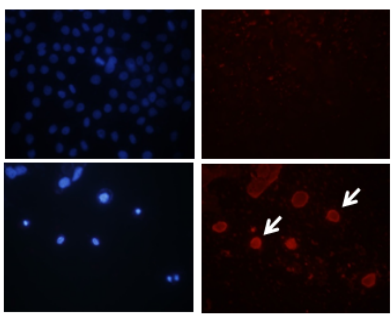

d) $E 2(20 \mu \mathrm{M})$

(e) Ful $(40 \mu \mathrm{M})$

(f) E2 $(20 \mu \mathrm{M})+$
Ful $(40 \mu \mathrm{M})$
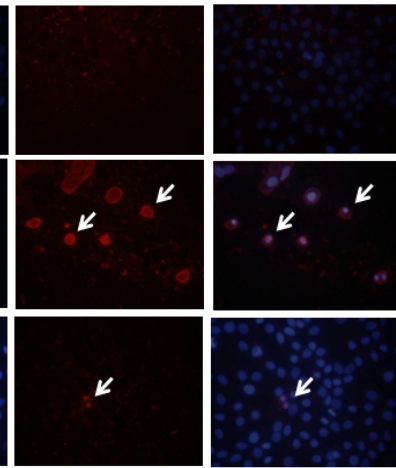
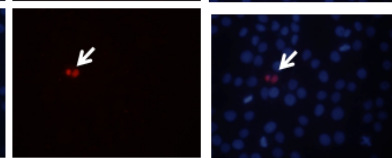

B

(a)
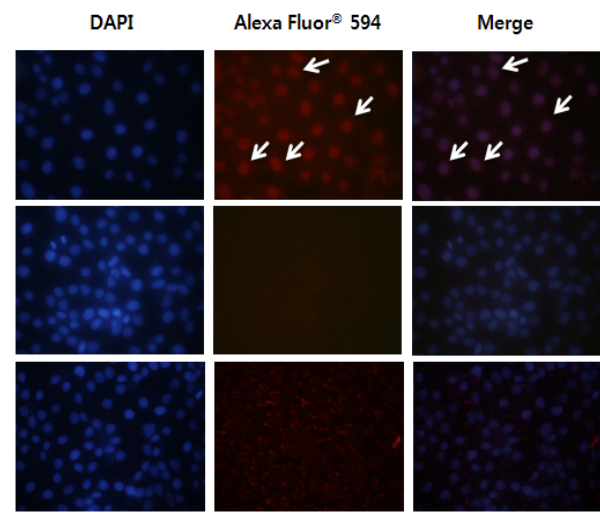

(b) $\mathrm{NE}$

(c)

EtOH $(0.1 \%)+$ DMSO $(0.4 \%)$

(d)
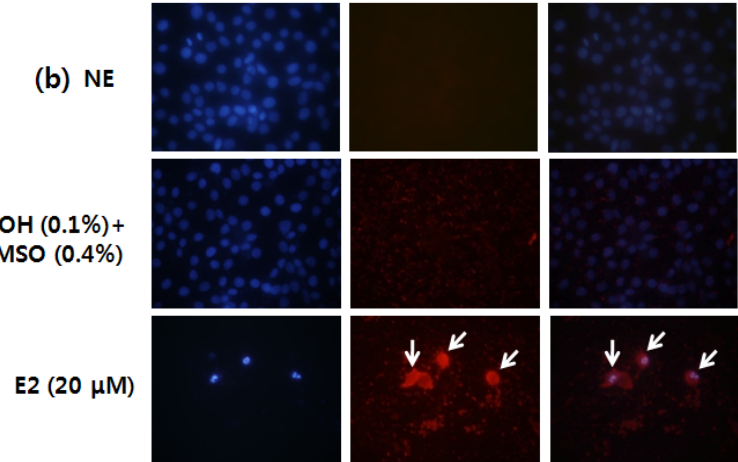

(e) Ful $(40 \mu \mathrm{M})$
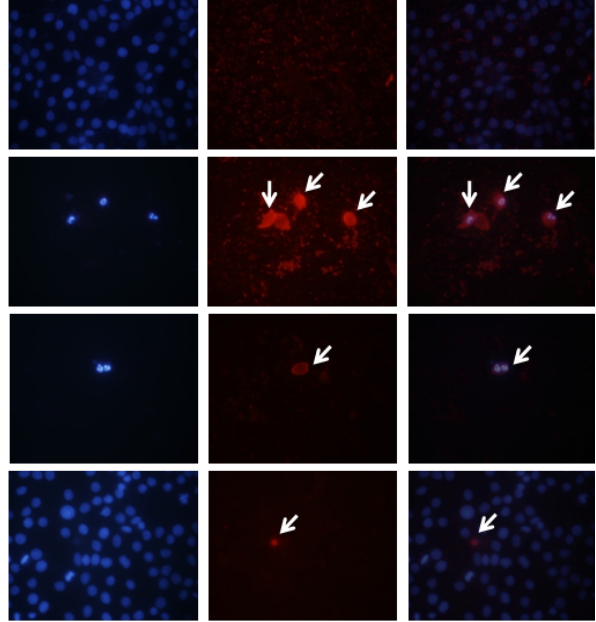

Fig. 4. Effects of $17 \beta$-estradiol, fulvestrant and $17 \beta$-estradiol plus fulvestrant on DNA fragmentation as measured by TUNEL assay. $\mathrm{CHO}$ cells were treated for $48 \mathrm{hr}$ with $0.1 \%$ ethanol plus $0.4 \%$ DMSO (negative control; c), $20 \mu \mathrm{M} 17 \beta$-estradiol (E2; d), $40 \mu \mathrm{M}$

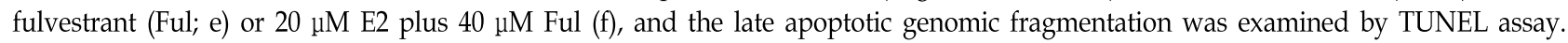
In addition, $\mathrm{CHO}$ cells were also treated with DNase I as a positive control to induce artificial DNA fragmentation (a) or terminal deoxynucleotidyl transferase was omitted as a negative assay control to remove nucleotide incorporation for probe staining (b). Photographs of (A) and (B) are representative pictures from two different areas of each slide. The left panels show nuclei stained with DAPI, the meddle panels show fragmented DNAs stained with Alexa Fluor ${ }^{\circledR}$ azide by TUNEL assay, and the right panels show the merged photographs of both DAPI and fluor stains. The arrows indicate nuclei with fragmented DNA. All photographs of both (A) and (B) are taken at 400x magnification.

관찰한 결과, DNase I으로 처리된 양성 대조군에서는 DAPI로 염색된 대부분의 세포핵이 TUNEL 양성반응으로 확인된 반면 (Fig. 4A-a, Fig. 4B-a), TdT를 처리하지 않은 음성 대조군(Fig. 4A- b, Fig. 4B-b)과 E2와 Ful의 혼합용매 처리군(Fig. 4A-C, Fig. 4B-c)에서는 DAPI로 염색된 모든 세포핵에서 TUNEL 양 성반응이 나타나지 않았다. 한편, $20 \mu \mathrm{M}$ 의 $\mathrm{E} 2$ 로 처리된 $\mathrm{CHO}$ 세포주에서는 DAPI로 염색된 거의 모든 핵에서 TUNEL 양성 반응을 보였다(Fig. $4 \mathrm{~A}-\mathrm{d}$, Fig. 4B-d). 이와는 달리, $40 \mu \mathrm{M}$ 의 Ful로 처리된 세포에서는 TUNEL 양성반응을 나타내었으나, $\mathrm{E} 2$ 처리군과 비교하여 현저히 낮은 비율로 관찰되었다(Fig. $4 \mathrm{~A}-\mathrm{e}, \mathrm{Fig}$. 4B-e). 흥미롭게도 $20 \mu \mathrm{M}$ 의 E2와 $40 \mu \mathrm{M}$ 의 Ful을 동시에 처리했을 경우에는 E2에 의해 유도된 높은 비율의 TUNEL 양성 반응이 Ful에 의하여 현저하게 억제되는 것으로 나타났다(Fig. 4A-f, Fig. 4B-f). 이러한 각각의 처리에 따른 DNA 분절 효과는 slide 내 관찰된 부위별 $\mathrm{CHO}$ 세포에 따라 다소 차이가 발견되었지만, 전체적으로 일관성 있는 유사한 비율의 양상을 나타내었다. 이에 대한 각 slide 내 부위별
TUNEL 반응을 비교 분석하기 위한 예로써, 관찰된 다양한 부위들 중 대표적인 다른 두 부위에 대한 TUNEL assay 결과 를 Fig. $4 \mathrm{~A}$ 와 Fig. $4 \mathrm{~B}$ 에 각각 제시하였다.

\section{고 찰}

본 연구는 고농도의 $\mathrm{E} 2$ 처리가 배양된 $\mathrm{CHO}$ 세포주의 증식 을 억제함을 보였으며, 이러한 결과는 이전에 보고된 일부 유 형의 유방암세포와 전립선 암세포에서 비교적 낮은 농도의 에스트로겐 처리에 의한 세포사멸 촉진과 증식억제효과[13, 20] 그리고 최근에 보고된 자궁경부암세포에서의 고농도 에스 트로겐에 의한 세포증식 억제효과의 결과들과 일치한다[14]. 자궁경부암세포주인 $\mathrm{HeLa}$ 세포에 대한 이전의 연구결과와 같 이, 낮은 농도의 E2 $(0.01-1 \mu \mathrm{M})$ 는 모든 처리기간 동안(6일-10 일) 배양된 $\mathrm{CHO}$ 세포의 증식에 영향을 미치지 않았다. 그러 나, $15 \mu \mathrm{M}$ 이상의 E2 처리는 모든 처리기간에서 세포증식 억 제효과를 보였을 뿐만 아니라, 처리기간이 길어질수록 억제효 
과가 점차 증가함을 보였다(Fig. 1A-1C). 이러한 E2에 의한 세 포증식 억제효과는 DNA 분절에 의해 매개되는 세포사멸과 최소한 부분적으로 관련되는 것으로 여겨진다. 본 연구의 TUNEL assay 결과에서 나타난 바와 같이, E2 처리는 다수의 $\mathrm{CHO}$ 세포 내 DNA 분절화를 유도하였다. 이러한 결과는 최근 에 보고된 $3 \mathrm{AO}$ 인간 난소암세포주에서 $\mathrm{MAPK}$ 와 연관된 세포 사멸 과정을 통해 일어나는 세포증식 억제효과의 결과와도 일치한다[12]. 그러나 이러한 결과와는 달리, human과 rabbit 유래 난소의 과립막세포 또는 표면상피세포와 같은 난소유래 세포에서는 E2가 세포증식을 유도한다는 이전의 상반된 보고 $[2,6,19]$ 는 E2의 작용이 세포가 유래된 species 뿐만 아니라 표적조직세포의 유형과 세포의 특이적인 생리적 상태에 따라 다른 효과를 나타낼 수 있음을 시사한다.

$\mathrm{E} 2$ 가 세포성장을 억제하는 자세한 분자생물학적 기전은 아 직 잘 알려져 있지 않지만, 특정 조직세포 또는 생리적 조건에 서 세포증식이 억제됨을 나타내는 증거들이 보고되어 왔다. 먼저, 장기간의 E2 결핍에 대한 저항력을 가진 ER-양성 유방암 세포(MCF-7:5C)는 E2의 생리적 농도 $\left(10^{-14}-10^{-8} \mathrm{M}\right)$ 에서 세포증 식이 감소하는데, 이는 미토콘드리아 막의 파괴로 인한 cytochrome c 방출, poly(ADP-ribose) polymerase (PARP) 단백질 분절 및 caspase-8 활성증가 등을 통한 미토콘드리아 세포사멸 경로에 기인하는 것으로 보고되었다[11]. 또한 유사한 연구에 따르면, 다른 유형의 유방암 세포주인 MCF-7 유래 LTED 세포 에서 생리적 농도 $\left(10^{-10}-10^{-8} \mathrm{M}\right)$ 의 E2 처리가 DNA 분절 유도 및 death receptor 단백질 Fas와 이의 리간드 FasL의 발현을 증가시킴으로써 세포사멸을 유도하는 것으로 보고되었다[24]. 따라서, 이전의 연구결과들로부터 보고된 유방암세포에서 의 E2에 의한 세포사멸 효과 그리고 본 연구에서 제시된 E2에 의한 $\mathrm{CHO}$ 세포에서의 TUNEL 양성반응 결과로 비추어 볼 때, 고농도 $\mathrm{E} 2$ 에 의한 $\mathrm{CHO}$ 세포증식 억제효과가 최소한 부분 적으로는 DNA 분절유도를 포함하는 세포 사멸경로들 중의 일부 기전에 의해 매개될 수 있을 것으로 여겨진다.

$\mathrm{Ful}$ 은 유방암 세포에서 $\mathrm{ER}$ 에 대한 길항제로서 알려져 있으 며, 임상 치료제의 하나로 사용되어 왔다. 그러나, 본 연구결과 에서 나타난 바와 같이 $\mathrm{CHO}$ 세포에서의 Ful 효과는 E2에 의 한 세포증식 억제효과만큼 미치지는 못하지만 20-40 $\mu \mathrm{M}$ 의 모 든 처리기간에서 증식 억제효과를 보였을 뿐만 아니라(Fig. 2A-C), E2 $(20 \mu \mathrm{M})$ 와 동시에 처리하였을 경우 Ful $(40 \mu \mathrm{M})$ 은 $\mathrm{E} 2$ 에 의한 세포증식 억제효과에 영향을 미치지 못하거나(6일) 오히려 억제효과를 촉진시킴으로써(8, 10일), $\mathrm{Ful}$ 이 최소한 $\mathrm{CHO}$ 세포에서는 E2 작용에 대한 길항제가 아닌 약한 작용제 로서 역할을 하는 것으로 보여진다. 이 결과와 일치하게 최근 의 연구보고에 의하면, 인간 난소암세포주의 하나인 $3 \mathrm{AO}$ 에서 Ful만 처리했을 경우 $(10 \mu \mathrm{M})$ 에는 $\mathrm{E} 2$ 에 의한 세포 증식 억제효 과와 비교하여 훨씬 낮은 억제효과를 보였으나, E2 $(1 \mu \mathrm{M})$ 와 함께 처리된 $\mathrm{Ful}(10 \mu \mathrm{M})$ 은 $\mathrm{E} 2$ 의 단독처리에 의한 증식 억제효
과를 증가시킴으로써 $\mathrm{Ful}$ 이 E2에 대한 협력적 작용을 하며, 길항적 작용이 되지 못함을 제시한 바 있다. 따라서 이러한 $\mathrm{Ful}$ 의 세포증식 억제기전은 잘 알려져 있지 않지만, 최근의 연구 결과들은 특정 종의 난소유래 세포주에서 독립적으로 또는 E2와 함께 협력적으로 세포증식을 억제시킬 수 있는 증 거를 제공하였다[12, 28].

그러나 흥미롭게도, 이러한 세포증식 억제효과에 대한 E2 작용제로서의 Ful의 기능과는 달리 Ful은 E2에 의한 DNA 분 절효과를 촉진시키지 못하고 오히려 억제시킴으로써, $\mathrm{CHO}$ 세포사멸과 연관된 기전과 관련하여서는 Ful이 E2에 의한 신 호전달기전에 협동적으로 작용하기 보다는 오히려 억제 또는 길항적으로 영향을 미치는 것으로 사료된다. $\mathrm{Ful}$ 의 $\mathrm{CHO}$ 세포 에 대한 세포증식 억제효과 및 이에 대한 E2와의 협동적 작용 그리고 세포사멸 관련 DNA 분절에 대한 E2 작용의 억제효과 등에 대한 구체적인 분자생화학적 신호전달 기전은 향후 규명 되어야 할 부분이다.

결론적으로, 본 연구의 결과는 고농도의 $\mathrm{Ful}$ 이 $\mathrm{CHO}$ 세포주 의 증식억제를 유도할 뿐만 아니라 E2에 의한 증식억제 효과 를 촉진함으로써, $\mathrm{CHO}$ 세포에 있어서는 기존에 알려진 E2 작용에 대한 길항제로서의 역할이 아닌 협동적 기능을 나타내 며, 세포사멸과 연관된 DNA 분절에 대한 효과는 E2의 작용에 대한 협동적 기능이 아닌 억제적 기능을 나타냄을 제시한다. 이러한 결과는 E2와 Ful에 의한 세포증식 억제와 이들에 의한 $\mathrm{DNA}$ 분절을 통한 세포사멸 관련기전은 서로 다른 신호전달 경로를 통해 매개됨을 시사한다.

\section{감사의 글}

이 논문은 2012년도 경남과학기술대학교 기성회 연구비 지 원에 의하여 연구되었으며 이에 감사드립니다.

\section{References}

1. Auersperg, N., Wong, A. S., Choi, K. C., Kang, S. K. and Leung, P. C. 2001. Ovarian surface epithelium: biology, endocrinology, and pathology. Endocr Rev 22, 255-288.

2. Bai, W., Oliveros-Saunders, B., Wang, Q., Acevedo-Duncan, M. E. and Nicosia, S. V. 2000. Estrogen stimulation of ovarian surface epithelial cell proliferation. In Vitro Cell Dev Biol Anim 36, 657-666.

3. Chen, G. G., Zeng, Q. and Tse, G. M. 2008. Estrogen and its receptors in cancer. Med Res Rev 28, 954-974.

4. Choi, K. C., Kang, S. K., Tai, C. J., Auersperg, N. and Leung, P. C. 2001. Estradiol up-regulates antiapoptotic Bcl-2 messenger ribonucleic acid and protein in tumorigenic ovarian surface epithelium cells. Endocrinol 142, 2351-2360.

5. Cui, J., Shen, Y. and Li, R. 2013. Estrogen synthesis and signaling pathways during aging: from periphery to brain. Trends Mol Med 19, 197-209. 
6. Cunat, S., Hoffmann, P. and Pujol, P. 2004. Estrogens and epithelial ovarian cancer. Gynecol Oncol 94, 25-32.

7. Hall, J. M., Couse, J. F. and Korach, K. S. 2001. The multifaceted mechanisms of estradiol and estrogen receptor signaling. J Biol Chem 276, 36869-36872.

8. Hempling, R. E., Wong, C., Piver, M. S., Natarajan, N. and Mettlin, C. J. 1997. Hormone replacement therapy as a risk factor for epithelial ovarian cancer: results of a case-control study. Obstet Gynecol 89, 1012-1016.

9. Howell, A. 2006. Fulvestrant ('Faslodex'): current and future role in breast cancer management. Crit Rev Oncol Hematol $57,265-273$.

10. Lee, Y., Renaud, R. A., Friedrich, T. C. and Gorski, J. 1998. Estrogen causes cell death of estrogen receptor stably transfected cells via apoptosis. J Steroid Biochem Mol Biol 67, 327-332.

11. Lewis, J. S., Meeke, K., Osipo, C., Ross, E. A., Kidawi, N., Li, T., Bell, E., Chandel, N. S. and Jordan, V. C. 2005. Intrinsic mechanism of estradiol-induced apoptosis in breast cancer cells resistant to estrogen deprivation. J Natl Cancer Inst 97, 1746-1759.

12. Li, Z. B., Chen, Y. X., Zhao, J. Y. and Lu, J. 2006. Effects of pharmacological concentrations of estrogens on growth of 3AO human ovarian cancer cells. Yi Chuan Xue Bao 33, 782-792.

13. McKenna, N. J., Lanz, R. B. and O'Malley, B. W. 1999. Nuclear receptor coregulators: cellular and molecular biology. Endocr Rev 20, 321-344.

14. Min, G. S. 2011. Inhibitory effects of high concentrations of estrogen, progesterone and tamoxifen on proliferation of HeLa in culture. J Life Sci 21, 1746-1751

15. Nelson, L. R. and Bulun, S. E. 2001. Estrogen production and action. J Am Acad Dermatol 45, S116-124.

16. Osborne, C. K., Wakeling, A. and Nicholson, R. I. 2004. Fulvestrant: an oestrogen receptor antagonist with a novel mechanism of action. Br J Cancer 90, S2-6.

17. Purdie, D., Green, A., Bain, C., Siskind, V., Ward, B., Hacker, N., Quinn, M., Wright, G., Russell, P. and Susil, B. 1995. Reproductive and other factors and risk of epithelial ovarian cancer: an Australian case-control study. Survey of Women's Health Study Group. Int J Cancer 62, 678-684.

18. Purdie, D. M., Bain, C. J., Siskind, V., Russell, P., Hacker, N. F., Ward, B. G., Quinn, M. A. and Green, A. C. 1999. Hormone replacement therapy and risk of epithelial ovarian cancer. Br J Cancer 81, 559-563.

19. Rao, M. C., Midgley, A. R. Jr. and Richards, J. S. 1978. Hormonal regulation of ovarian cellular proliferation. Cell 14, 71-78.

20. Robertson, C. N., Roberson, K. M., Padilla, G. M., O'Brien, E. T., Cook, J. M., Kim, C. S. and Fine, R. L. 1996. Induction of apoptosis by diethylstilbestrol in hormone-insensitive prostate cancer cells. J Natl Cancer Inst 88, 908-917.

21. Robertson, J. F. 2007. Fulvestrant (Faslodex) - how to make a good drug better. Oncologist 12, 774-784.

22. Saintier, D., Khanine, V., Uzan, B., Ea, H. K., de Vernejoul, M. C. and Cohen-Solal, M. E. 2006. Estradiol inhibits adhesion and promotes apoptosis in murine osteoclasts in vitro. J Steroid Biochem Mol Biol 99, 165-173.

23. Seli, E., Guzeloglu-Kayisli, O., Cakmak, H., Kayisli, U. A., Selam, B. and Arici, A. 2006. Estradiol increases apoptosis in human coronary artery endothelial cells by up-regulating Fas and Fas ligand expression. J Clin Endocrinol Metab 91, 4995-5001.

24. Song, R. X., Mor, G., Naftolin, F., McPherson, R. A., Song, J., Zhang, Z., Yue, W., Wang, J. and Santen, R. J. 2001. Effect of long-term estrogen deprivation on apoptotic responses of breast cancer cells to 17beta-estradiol. J Natl Cancer Inst 93, 1714-1723.

25. Tora, L., White, J., Brou, C., Tasset, D., Webster, N., Scheer, E. and Chambon, P. 1989. The human estrogen receptor has two independent nonacidic transcriptional activation functions. Cell 59, 477-487.

26. Wardell, S. E., Marks, J. R. and McDonnell, D. P. 2011. The turnover of estrogen receptor a by the selective estrogen receptor degrader (SERD) fulvestrant is a saturable process that is not required for antagonist efficacy. Biochem Pharmacol 82, 122-130.

27. Weiss, N. S., Lyon, J. L., Krishnamurthy, S., Dietert, S. E., Liff, J. M. and Daling, J. R. 1982. Noncontraceptive estrogen use and the occurrence of ovarian cancer. J Natl Cancer Inst 68, 95-98.

28. Wright, J. W., Stouffer, R. L. and Rodland, K. D. 2005. High-dose estrogen and clinical selective estrogen receptor modulators induce growth arrest, p21, and p53 in primate ovarian surface epithelial cells. J Clin Endocrinol Metab 90, 3688-3695.

29. Yaffe, K., Sawaya, G., Lieberburg, I. and Grady, D. 1998. Estrogen therapy in postmenopausal women: effects on cognitive function and dementia. JAMA 279, 688-695.

30. Yeh, W. L., Shioda, K., Coser, K. R., Rivizzigno, D., McSweeney, K. R. and Shioda, T. 2013. Fulvestrant-induced cell death and proteasomal degradation of estrogen receptor a protein in MCF-7 cells require the CSK c-Src tyrosine kinase. PLoS One 8, e60889.

31. Yoo, C., Kim, S. B., Ahn, J. H., Jung, K. H., Ahn, Y., Gong, G., Kim, H. H., Kim, H. J., Son, B. H. and Ahn, S. H. 2011. Efficacy of fulvestrant in heavily pretreated postmenopausal women with advanced breast cancer: a preliminary report. J Breast Cancer 14, 135-139. 


\section{초록 : 17ß-Estradiol의 $\mathrm{CHO}$ 세포 항 증식작용에 대한 fulvestrant의 효과}

김현희 $^{1} \cdot$ 박형철 $^{2}$ - 민계식 ${ }^{3 *}$

( ${ }^{1}$ 경남과학기술대학교 바이오과학대학 제약공학과, ${ }^{2}$ 경상대학교 응용생명과학부, ${ }^{3}$ 경남과학기술대학교 바이 오과학대학 간호학과)

에스트로겐은 조직세포의 유형과 이들의 생리적 상태에 따라 세포증식을 촉진 또는 억제 시킬 수 있으며, 주로 에스트로겐 수용체(ER)에 의해 매개되는 신호전달 경로를 통해 작용한다. 이 연구는 특히 유방암세포에서 $\mathrm{ER}$ 에 대한 길항제로 잘 알려진 fulvestrant (Ful)가 $\mathrm{CHO}$ 세포주의 증식 및 세포사멸에 미치는 영향과 이들에 대한 $17 \beta-$ estradiol (E2)의 작용에 미치는 효과를 조사하고자 하였다. 이를 위하여 먼저 다양한 농도의 E2, Ful 및 E2 plus Ful의 처리기간에 따라 세포증식에 미치는 효과를 조사하였다. Cell proliferation 분석에서, 6-10일의 처리기간 동 안 E2는 $1 \mu \mathrm{M}$ 의 농도까지는 세포증식에 영향을 주지 않았지만, 15-40 $\mu \mathrm{M}$ 에서는 처리기간의 증가에 따라 점진적 으로 현저히 세포증식을 억제하였다. 흥미롭게도 Ful 또한 $1 \mu \mathrm{M}$ 의 농도까지는 세포증식에 영향을 주지 않았지만, 10-40 $\mathrm{\mu M}$ 에서는 농도 및 시간 의존적인 세포증식 억제효과를 보였다. 뿐만 아니라, Ful은 10일 동안 E2와의 혼합 처리에서 E2에 의한 세포증식 억제효과를 감소시키기 보다는 오히려 증대시켰다. 따라서 Ful은 $\mathrm{CHO}$ 세포에서 $\mathrm{E} 2$ 의 항 증식작용에 대한 길항적 효과를 갖지 않음을 제시한다. 한편, E2 및 Ful에 의한 DNA 분절효과를 확인하 기 위한 TUNEL assay에서 $20 \mu \mathrm{M}$ 의 E2로 처리된 $\mathrm{CHO}$ 세포주에서는 DAPI로 염색된 거의 모든 핵에서 TUNEL 양성반응이 나타났으며, $40 \mu \mathrm{M} \mathrm{Ful} \mathrm{및} 20 \mu \mathrm{M}$ E2 plus $40 \mu \mathrm{M}$ Ful로 처리된 CHO 세포주에서는 TUNEL 양성반응 을 보였으나, E2 처리군과 비교하여 현저히 낮은 비율로 나타났다. 이러한 결과는 Ful이 CHO 세포에서 E2의 항 증식작용에 대한 길항적 효과를 갖지 않으며, E2와 Ful에 의한 세포증식 억제와 DNA 분절을 통한 세포사멸 관련 기전은 다른 신호전달 경로를 통해 매개됨을 시사한다. 